\title{
EFEKTIVITAS LAYANAN BIMBINGAN KELOMPOK DENGAN MEDIA CYNEMA THERAPHY UNTUK MENINGKATKAN SELF EFFICACY SISWA
}

\author{
Iga Vinaya Aginza, Maghfirotul Lathifah \\ Universitas PGRI Adi Buana Surabaya, \\ iga.vinaya@gmail.com
}

\begin{abstract}
This study aims to determine the effectiveness of using the cynema therapy media in group guidance to increase student self-efficacy. This research approach is quantitative. This type of research uses the One Group Pre-Test Post-Test Design research design. This study consisted of the dependent variable, namely self-efficacy and the independent variable, namely group guidance services using cynema therapy media. The population in this study were high school and vocational high school students in RT 3 and 4 in Kepuh Kiriman village, from that population, 5 students were taken using a purposive sampling technique. The results of this study indicate that there is an increase in the average score of students' self-efficacy in Kepuh Kiriman village from the pre-test average score of 36.2 in the low category and the average score after the student was given treatment, the average post-test result was 66 high category. Thus, it proves that there is a significant influence on the use of cynema therapy media in group guidance to increase student self-efficacy.
\end{abstract}

Keywords: Cynema Therapy, Group Guidance, Self Efficacy

\begin{abstract}
Abstrak
Penelitian ini bertujuan untuk mengetahui efektivitas penggunaan media cynema theraphy dalam bimbingan kelompok untuk meningkatkan self efficacy pada siswa. Pendekatan penelitian ini adalah kuantitatif. Jenis penelitian ini menggunakan rancangan penelitian One Group Pre-Test Post-Test Design. Penelitian ini terdiri dari variabel terikat yaitu self efficacy dan variabel bebas yaitu adalah layanan bimbingan kelompok dengan menggunakan media cynema theraphy. Populasi dalam penelitian ini adalah siswa SMA dan SMK di RT 3 dan 4 di Desa Kepuh Kiriman, dari populasi itu diambil sampel penelitian 5 siswa dengan menggunakan teknik purposive sampling. Hasil penelitian ini menunjukan terdapat peningkatan rata-rata skor self efficacy siswa di Desa Kepuh Kiriman dari nilai rata-rata pre-test 36,2 dalam kategori rendah dan skor rata-rata setelah siswa diberikan treatment, rata-rata hasil post-test 66 dalam kategori tinggi. Sehingga, membuktikan bahwa adanya pengaruh yang signifikan terhadap penggunaan media cynema theraphy dalam bimbingan kelompok untuk meningkatkan self efficacy siswa.
\end{abstract}

Kata Kunci: Cynema Therapy, Bimbingan Kelompok, Self Efficacy

\section{PENDAHULUAN}

Self efficacy adalah siswa yang mempunyai keyakinan dalam mengatasi beranekaragam masalah yang muncul pada diri siswa. (Bandura, 2010). Self efficacy adalah peran motivasi siswa dalam pencapaiannya. Pertimbangan keyakinan diri siswa usaha yang dimiliki siswa dalam menyelesaikan tugasnya dan lamanya waktu yang dibutuhkan oleh siswa. self efficacy Siswa tinggi mampu menggunakan usaha untuk mengatasi permasalahannya dan akan lebih giat dalam belajar, dan lebih percaya diri, sedangkan siswa yang memiliki self efficacy siswa rendah merasa kurang dapat meningkatkan usahanya atau tidak dapat mengatasi masalah yang ada dan lebih 
ragu dengan kemampuan yang dimilikinya (Betz \& Schifano, 2000).

Berdasarkan hasil observasi yang dilakukan oleh peneliti, fenomena yang sering muncul dikalangan siswa salah satunya di siswa SMK di Desa Kepuh Kiriman Sidoarjo. Terdapat siswa yang mengalami hambatan belajar karena memiliki self efficacy yang rendah, terbukti dari kondisi siswa yang belum mampu mengatur jadwal belajar dirumah terutama dalam mengerjakan tugas sekolah, selain itu siswa juga kurang disiplin pada saat kegiatan belajar mengajar, siswa pun cenderung menghindari tugas-tugas yang sulit, beberapa siswa merasa tugas yang didapat sebagai tekanan bukan tantangan sehingga pada saat guru memberikan tugas yang dirasa cukup banyak tidak jarang siswa mengeluh kepada guru. Pada saat mengerjakan tugas atau ujian beberapa siswa melihat atau meniru jawaban teman, hal itu yang membuat siswa merasa tidak percaya diri akan kemampuan dirinya atau tidak yakin pada jawaban sendiri, jika dihadapkan pada tugas yang sulit atau rumit siswapun cenderung mudah menyerah, banyak siswa tidak memiliki perencanaan untuk mengatur jadwal belajar dan cenderung akan belajar saat akan ujian saja tidak rutin setiap hari meriview materi pembelajaran setelah mereka dapatkan. Kejadian ini terjadi selama masa pandemik.

Self efficacy dianggap sebagai salah satu faktor, yang di definisikan sebagai keyakinan pada kemampuan siswa untuk mengatur perilaku dan keyakinan siswa yang diperlukan agar menghasilkan pencapaian tertentu (Bosscher \& Smit, 1998). Beberapa faktor yang mempengaruhi self efficacy siswa diantaranya faktor pengalaman menguasai kemampuan: keberhasilan siswa mengerjakan tugas yang sulit untuk meningkatkan keyakinan diri, model sosial: keyakinan diri siswa akan meningkat ketika mengobservasi temannya yang memiliki kompetensi yang sama, persuasi sosial: komunikasi sosial yang digunakan meyakinkan orang lain yang dapat meningkatkan atau menurunkan keyakinan seseorang dalam kondisi tertentu, kondisi fisik dan emosi: emosi yang dalam (intens) dan kuat yang cenderung menurunkan kinerja seseorang dibandingkan dengan emosi yang tidak dalam (intens) (Gerbino, 2020).

Dampak positif bila self efficacy dapat ditangani, maka siswa akan mengalami perubahan dari keyakinan diri yang negatif menjadi positif, siswa akan lebih yakin terhadap kesuksesan dalam menghadapi masalah, lebih giat dalam belajar, tidak akan pernah terlambat sekolah, dan lebih percaya diri. Apabila self efficacy yang rendah segera ditangani, maka siswa akan mengalami perubahan pada dirinya, seperti menganggap dirinya yang mampu dalam mengerjakan sesuatu, berusaha lebih keras untuk mengatasi tantangan apapun, lebih percaya diri dalam hal apapun, mau mencoba dan tidak mudah menyerah (Miehls \& Moffatt, 1999).

Dari pemaparan diatas untuk meningkatkan self efficacy siswa dapat dilakukan dengan menggunakan media cynema theraphy dalam bimbingan kelompok. Peneliti menggunakan media cynema theraphy dalam bimbingan kelompok karena layanan bimbingan dan konseling yang diberikan kepada siswa dalam bentuk kelompok. Dalam bimbingan kelompok, konselor harus melakukan pendekatan dengan menggunakan media sebagai alat untuk membantu siswa untuk menambah pengetahuan dan membantu masalah yang dialami oleh siswa. Media yang dimaksud adalah media film yang bagaimana menampilkan gambaran berupa informasi yang positif. Film adalah media yang dapat membantu siswa dalam pengetahuan. Film juga efektif untuk membantu proses bimbingan kelompok dengan materi pengetahuan yang diberikan. Jadi dapat disimpulkan peneliti akan menggunakan layanan bimbingan kelompok dengan 
media film untuk meningkatkan self efficacy siswa.

\section{METODE PENELITIAN}

Teknik penelitian ini menggunakan quasi-Eksperimental menggunakan rancangan one group pre-test post-test design (Meng \& Berger, 2019) yang bertujuan untuk mengetahui evektivitas layanan bimbingan kelompok dengan menggunakan media cynema theraphy untuk meningkatkan self efficacy siswa SMK. Rancangan penelitian ini diuraikan pada gambar dibawah ini.

\section{Gambar 1. Rumus One Group Pretest Postest Design}

Keterangan:

$\mathrm{T}_{1}$ adalah pretest (pengukuran variabel terikat yaitu self efficacy dengan menggunakan skala pengukuran yang dikembangkan oleh peneliti).

$\mathrm{T}_{2}$ adalah posttest (pengukuran variabel terikat yaitu self efficacy dengan menggunakan skala pengukuran setelah kelompok subjek diberi layanan bimbingan kelompok dengan menggunakan cynema theraphy).

$\mathrm{X}_{\mathrm{t}}$ adalah treatment (pemberian layanan bimbingan kelompok dengan menggunakan cynema theraphy 3 kali dengan alokasi waktu 45 menit).

Penelitian ini menggunakan populasi siswa SMK di RT 3 dan 4 di Desa Kepuh Kiriman. Peneliti mengambil sampel sebanyak 5 siswa terpilih yang memenuhi kriteria dan memperoleh skor terendah terhadap self efficacy.

Metode pengumpulan data penelitian ini dengan intrumen penelitian yang menggunakan skala pengukuran yaitu skala likert. Skala pengukuran self efficacy sudah diuji kepada siswa kemudian hasilnya dianalisis dengan korelasi item soal untuk menguji validitas butir item dengab menggunakan r-tabel dengan nilai validitas 0,042 .
Analisis data penelitian ini memakai Uji Wilcoxon Non Parametrik pada SPSS versi 24.00. peneliti menggunakan teknik analisis data non paratekrik karena sampel yang diguanakan relative kecil.

\section{HASIL DAN PEMBAHASAN \\ Hasil}

Pada penelitian ini hasil yang didapat peneliti setelah di lakukan pretest, yang mana dari pre-test tersebut akan diberiathu berapa subyek yang akan mendapatkan treatment layanan bimbingan kelompok dengan media cynema theraphy untuk meningkatkan self efficacy siswa. Rentang penelitian

\begin{tabular}{|llll}
\hline $\mathrm{T}_{1}$ & $\mathrm{X}$ & $\mathrm{T}_{2}$ & $\begin{array}{l}\text { pada skala } \\
\text { pengukuran self }\end{array}$
\end{tabular}

efficacy siswa pada penelitian ini memakai rentang skor 1-3 dari banyaknya 21 butir pernyataan, sehingga kriteria ditentukan dengan cara:

$\underline{\text { Skor tertinggi - skala terendah }}$

\section{3}

Maka, untuk menentukan 3 kategori tersebut



Sebelum melakukan treatment layanan bimbingan kelompok menggunakan media cynema theraphy peneliti memberikan pre-test kepada 30 siswa, kemudian mendapatkan hasil 5 siswa yang mengalami self efficacy dengan skor terendah. Berikut 5 siswa yang menjadi sampel penelitian yang mengalami self efficacy rendah.

Tabel pre-test

\begin{tabular}{llll}
\hline No & Responden & Skor & Kategori \\
\hline 1 & MIC & 34 & Rendah \\
\hline 2 & RFI & 33 & Rendah \\
\hline 3 & NNA & 37 & Rendah \\
\hline 4 & MSM & 39 & Rendah \\
\hline
\end{tabular}




MHA $38 \quad$ Rendah

Setelah diperoleh hasil pre-test, siswa yang termasuk dalam kategori rendah akan menjadi subyek dalam penelitian, langkah selanjutnya akan diberi tindakan dengan diberikan treatment layanan bimbingan kelompok dengan menggunakan media cynema theraphy untuk meningkatkan self efficacy siswa.

Self efficacy yang terjadi pada siswa dari hasil treatment yang telah dilakukan peneliti sebanyak 5 kali pertemuan. Pada bagian ini peneliti akan menyajikan hasil setelah dilakukan treatment pada tabel berikut.

\begin{tabular}{llll}
\hline No & $\begin{array}{l}\text { Nama } \\
\text { Siswa }\end{array}$ & $\begin{array}{l}\text { Skor } \\
\text { Total }\end{array}$ & Kategori \\
\hline 1 & MIC & 69 & Tinggi \\
\hline 2 & RFI & 63 & Tinggi \\
\hline 3 & NNA & 69 & Tinggi \\
\hline 4 & MSM & 65 & Tinggi \\
\hline 5 & MHA & 64 & Tinggi \\
\hline
\end{tabular}

\section{PEMBAHASAN}

\section{a. Uji Hipotesis}

Analisis yang dilakukan peneliti, menyatakan adanya pengaruh signifikan pada bimbingan kelompok dengan menggunakan media cynema theraphy untuk meningkatkan self efficacy siswa SMK. Sehingga hipotesis yang diajukan pada penelitian ini adalah "Efektivitas Layanan Bimbingan Kelompok Dengan Menggunakan Media Cynema Theraphy Efektif Untuk Meningkatkan Self Efficacy Siswa", Karena nilai dari hasil analisis uji wilcoxon pada tabel test statistics 0,042 lebih kecil dari < 0,05, maka dapat disimpulkan bahwa Ha diterima. dengan demikian hipotesis diterima.
Tabel Hasil Uji Wilcoxon Self Efficacy

Pada Siswa $S M K$

\section{Ranks}

\begin{tabular}{|c|c|c|c|c|}
\hline & & $\mathrm{N}$ & $\begin{array}{l}\text { Mean } \\
\text { Rank }\end{array}$ & $\begin{array}{l}\text { Sum } \\
\text { of } \\
\text { Ranks }\end{array}$ \\
\hline \multirow[t]{4}{*}{$\begin{array}{l}\text { Post Test - } \\
\text { Pre Test }\end{array}$} & $\begin{array}{l}\text { Negative } \\
\text { Ranks }\end{array}$ & $0^{\mathrm{a}}$ & .00 & .00 \\
\hline & $\begin{array}{l}\text { Positive } \\
\text { Ranks }\end{array}$ & $5^{b}$ & 3.00 & 15.00 \\
\hline & Ties & $0^{c}$ & & \\
\hline & Total & 5 & & \\
\hline
\end{tabular}

a. Post Test $<$ Pre Test

b. Post Test $>$ Pre Test

c. Post Test $=$ Pre Test

Tabel Hasil Statistic Self Efficacy Pada Siswa SMK

Test Statistics ${ }^{\mathrm{a}}$

\begin{tabular}{ll} 
& $\begin{array}{l}\text { Post Test - Pre } \\
\text { Test }\end{array}$ \\
\hline $\mathrm{Z}$ & $-2.032^{\mathrm{b}}$ \\
\hline Asymp. Sig. (2-tailed) & .042 \\
\hline
\end{tabular}

a. Wilcoxon Signed Ranks Test

b. Based on negative ranks.

Berdasarkan hasil analisis uji wilcoxon pada tabel test statistics diatas diketahui Asymp. Sig (2-tailed) bernilai 0,042. Karena nilai 0,042 lebih kecil dari < 0,05, maka dapat disimpulkan bahwa Ha diterima. Artinya ada perbedaan antara self efficacy siswa untuk pre-test dan post-test, sehingga dapat disimpulkan bahwa efektif dengan penggunaan media cynema theraphy dalam bimbingan kelompok untuk meningkatkan self efficacy siswa SMK. Adapun deskripsi penggambaran saat melakukan proses treatment bimbingan kelompok menggunakan media cynema theraphy sebagai berikut.

\section{b. Treatment}

\section{Treatment 1}

Dilaksanakan pada tanggal 20 Januari 2021. Tahap awal konselor membuka pertemuan dengan salam dan berdoa bersama serta menanyakan kesiapanpara anggota kelompok, konselor mulai menjelaskan kembali 
peraturan, dan kode etik dalam bimbingan kelompok. Konselor menyampaikan materi yaitu dengan menayangkan film kurangnya percaya diri siswa sebelum pandemik. Setelah anggota kelompok melihat videonya, konselor meminta anggota untuk memberikan pendapatnya terhadap film yang sudah ditampilkan. Setelah itu konselor mengajak evaluasi terhadap topik yang sudah dibahas. Selanjutnya konselor menutupnya dengan memberikan kesimpulan dan berdoa.

2. Treatment 2 dilaksanakan pada tanggal 25 Januari 2021. Tahap awal konselor membuka pertemuan dengan salam dan berdoa bersama serta menanyakan kesiapanpara anggota kelompok, konselor mulai menjelaskan kembali peraturan, dan kode etik dalam bimbingan kelompok. Konselor menyampaikan materi yaitu dengan menayangkan film kurangnya percaya diri siswa saat pandemik. Setelah anggota kelompok melihat videonya, konselor meminta anggota untuk memberikan pendapatnya terhadap film yang sudah ditampilkan. Setelah itu konselor mengajak evaluasi terhadap topik yang sudah dibahas. Selanjutnya konselor menutupnya dengan memberikan kesimpulan dan berdoa.

3. Treatment 3 dilaksanakan pada tanggal 26 Januari 2021. Tahap awal konselor membuka pertemuan dengan salam dan berdoa bersama serta menanyakan kesiapanpara anggota kelompok, konselor mulai menjelaskan kembali peraturan, dan kode etik dalam bimbingan kelompok. Konselor menyampaikan topik yang akan dibahas yaitu solusi untuk meningkatkan kepercayaan diri pada self efficacy siswa. Selanjutnya konselor mulai menayangkan videonya tentang solusi untuk meningkatkan kepercayaan diri pada self efficacy siswa. Setelah anggota kelompok melihat videonya, konselor meminta kelompok untuk memberikan pendapatnya dan memecahkan solusi self efficacy sesuai dengan diri masingmasing. Setelah itu konselor mengajak evaluasi terhadap topik yang dibahas pada pertemuan kelima. Selanjutnya konselor mentupna dengan memberikan kesimpulan dan berdoa.

\section{KESIMPULAN}

Berdasarkan penelitian ini, Dapat menyimpulan bahwa bimbingan kelompok dengan media cynema theraphy kelas XI sangat berpengaruh. Self efficacy dapat ditingkatkan. Setelah peneliti memberikan treatment media cynema theraphy dalam kategori rendah menjadi meningkat.

Wilcoxon signed rank test, yang diperoleh memiliki hasil yaitu Asymp. Sig (2-tailed) bernilai -0,042. Karena nilai 0,042 yang diperoleh dibawah $<0,05$, maka disimpulkan bahwa $\mathrm{H}_{\mathrm{a}}$ diterima. Sehingga disimpulkan bahwa media cynema theraphy dalam bimbingan kelompok secara signifikan dapat meningkatkan self efficacy siswa SMK. hasil dari penelitian yang dilakukan diperoleh dengan analisis data dan pengujian hipotesis, sehingga dapat diperoleh kesimpulan yaitu terdapat hasil yang signifikan terhadap media cynema theraphy dalam bimbingan kelompok untuk meningkatkan self efficacy siswa SMK.

\section{REFERENSI}

Bandura, A. (2010). Self-efficacy Bandura. The Corsini Encyclopedia of Psychology, 1-3.

Betz, N. E., \& Schifano, R. S. (2000). Evaluation of an Intervention to Increase Realistic Self-Efficacy and Interests in College Women. Journal of Vocational Behavior, 56(1), 35-52. https://doi.org/10.1006/jvbe.1999.169 0

Bosscher, R. J., \& Smit, J. H. (1998). Confirmatory factor analysis of the general self-efficacy scale. Behaviour 
Research and Therapy, 36(3), 339-

343. https://doi.org/10.1016/S0005-

7967(98)00025-4

Gerbino, M. (2020). Self-efficacy. The

Wiley Encyclopedia of Personality

and Individual Differences, 1994,

387-391.

https://doi.org/10.1002/97811189708

43.ch243

Meng, J., \& Berger, B. K. (2019).

Research Design and Methods. Public

Relations Leaders as Sensemakers,

38-54.

https://doi.org/10.4324/97813158589

37-4

Miehls, D., \& Moffatt, K. (1999).

Development of Student Identity.

Journal of Teaching in Social Work, 19(1/2), 65-76.

https://doi.org/10.1300/J067v19n01

Sugiyono. (2010). Metode Penelitian

Pendidikan Pendekatan Kuantitatif,

Kualitatif, dan $R \& D$. 